\title{
ELECTROPHORESIS OF PROTEIN FRACTIONS FROM BOAR SEMINAL PLASMA, VESICULAR SECRETION AND EPIDIDYMAL PLASMA
}

\author{
U. LAVON, * P. A. BRIGGS and J. C. BOURSNELL \\ A.R.C. Unit of Reproductive Physiology and Biochemistry, Cambridge $\dagger$
}

(Received 23rd February 1972)

\begin{abstract}
Summary. The protein patterns of boar seminal plasma, vesicular secretion and epididymal plasma and of their fractions obtained by gel filtration and dialysis were further studied by gel disc electrophoresis and isoelectric focusing on polyacrylamide.

The majority of the seminal plasma proteins originate in the seminal vesicles and the quantitative contribution of the epididymides to the protein pattern is small. Proteins $\mathrm{A}, \mathrm{B}$ and $\mathrm{H}$ were found to be mixtures of large numbers of proteins which were identified and characterized.
\end{abstract}

\section{INTRODUCTION}

Some of the early publications concerning boar seminal fluids indicated a greater complexity of the protein fractions than could be assumed from the identification of the three major proteins, A, B and $H$ (Boursnell, Nelson \& Cole, 1966; Nelson \& Boursnell, 1966; Boursnell \& Briggs, 1969).

Recently Schellpfeffer \& Hunter (1970) and Lavon \& Boursnell (1971) studied the contribution of the vesicular secretion and epididymal plasma to the protein pattern of boar seminal plasma. It became apparent by electrophoresis on acrylamide gel that the protein fractions obtained by gel filtration alone represent mixtures of several proteins.

It was the aim of the present study to investigate further the protein patterns employing the methods of gel disc electrophoresis and isoelectric focusing on polyacrylamide used by Lavon \& Boursnell (1971). Particular use was made of the fractions obtained by gel filtration and dialysis of seminal plasma and vesicular secretion (Boursnell et al., 1966; Boursnell \& Briggs, 1969) and also of epididymal plasma treated in the same way. It was hoped to determine as far as possible the origins of the various seminal plasma protein fractions revealed by acrylamide gel studies.

\section{Collection of fluids}

\section{MATERIALS AND METHODS}

Vesicular secretion was obtained from seminal vesicles freshly excised from slaughterhouse material as described by Boursnell, Hartree \& Briggs (1970).

* Present address: Department of Zoology, University of Tel Aviv, Isracl.

† Postal address: Animal Research Station, 307 Huntingdon Road Cambridge CB3 0J(2. 
Seminal plasma was obtained from ejaculates of boars housed at the Animal Research Station as described by Boursnell et al. (1970). Epididymal semen from freshly excised epididymides was collected following the method of Lasley \& Bogart (1944) as described by Walton (1956). Fluids were separated from spermatozoa by centrifugation at $10,000 \mathrm{~g}$ for $20 \mathrm{~min}$ at room temperature and the supernatants were stored at $-20^{\circ} \mathrm{C}$ until required.

\section{Separation of fractions $A$ Dial and B Dial by dialysis}

Samples of $50 \mathrm{ml}$ seminal plasma and $10 \mathrm{ml}$ vesicular secretion were dialysed against three changes of veronal buffer, $\mathrm{pH} 8 \cdot 0, I=0.015$ (Miller \& Golder, 1950) for $24 \mathrm{hr}$ at $4^{\circ} \mathrm{C}$ as described by Boursnell \& Nelson (1965) and Boursnell et al. (1966). The precipitate (fraction B Dial) was separated from the supernatant (fraction A Dial) by centrifugation at $10,000 \mathrm{~g}$ for $20 \mathrm{~min}$ at room temperature. The precipitate was dissolved in acetate buffer, $\mathrm{pH} 4 \cdot 0, I=0 \cdot 3$ (Miller \& Golder, 1950) and the dialysis was repeated in order to remove possible traces of fraction A Dial. The final precipitate was redissolved as far as possible in $10 \mathrm{ml}$ acetate buffer, $\mathrm{pH} 4.0$.

\section{Separation of proteins by gel filtration}

Gel filtration of seminal plasma and vesicular secretion and of their fractions obtained by dialysis was carried out on Sephadex G-200 columns (Pharmacia, Great Britain, Ltd, London) at $\mathrm{pH} 4 \cdot 0, I=0 \cdot 3$ as described by Boursnell et al. (1966). For the separation of epididymal plasma proteins, smaller columns $(25 \times 1 \mathrm{~cm})$ were prepared either with Sephadex G-200 or with Sepharose 6B (Pharmacia, Great Britain, Ltd, London). The proteins were eluted from the Sephadex column with acetate buffer, $\mathrm{pH} 4 \cdot 0$, and with phosphate buffer, $\mathrm{pH}$ $7 \cdot 0, I=0 \cdot 3$ (Miller \& Golder, 1950) and from the Sepharose 6B column with the $\mathrm{pH} 4.0$ buffer.

The protein content in the gel filtration fractions was determined by UV absorption at $280 \mathrm{~nm}$ using a Uvicord II Instrument and Recorder (LKB Instruments Ltd, South Croydon, Surrey, CR2 8YD, U.K.) connected to a Chromafrac fraction collector and Chromapump (Baird \& Tatlock Ltd, Chadwell Heath, Essex, U.K.). The Chromapump was set to deliver fractions of $6.0 \mathrm{ml}$ at a flow rate of $21.6 \mathrm{ml} / \mathrm{hr}$ for all seminal plasma and vesicular secretion samples. For the epididymal plasma samples, a flow rate of $2.4 \mathrm{ml} / \mathrm{hr}$ and $6 \cdot 0-\mathrm{ml}$ fractions were used.

The fractions obtained by dialysis and gel filtration of the various fluids (not B Dial) were dialysed against three changes of distilled water and freeze dried. The freeze-dried material was dissolved as far as possible in $0.25 \mathrm{~m}-\mathrm{NaCl}$ before the electrophoresis and the solutions were centrifuged at $10,000 \mathrm{~g}$ for 10 min at room temperature in order to remove undissolved material.

\section{Gel disc electrophoresis}

All samples were separated at $\mathrm{pH} 4.5$ and the epididymal plasma was also separated at $\mathrm{pH} 8.6$ following the methods of Reisfeld, Lewis \& Williams (1962) and Davis (1964), respectively, as described by Lavon \& Boursnell (1971) and Lavon (1972). 
Isoelectric focusing

This was performed on polyacrylamide-ampholine plates of $\mathrm{pH}$ range 3 to 10 (LKB Instruments Ltd, South Croydon, Surrey CR2 8YD U.K.), which were prepared as described by Lavon \& Boursnell (1971) and Lavon (1972).

\section{RESULTS}

\section{Gel filtration}

The protein patterns of the seminal plasma and vesicular secretion and of their fractions obtained by dialysis (A Dial and B Dial), as eluted from the Sephadex G-200 column, are presented in Text-figs 1 and 2, respectively. It

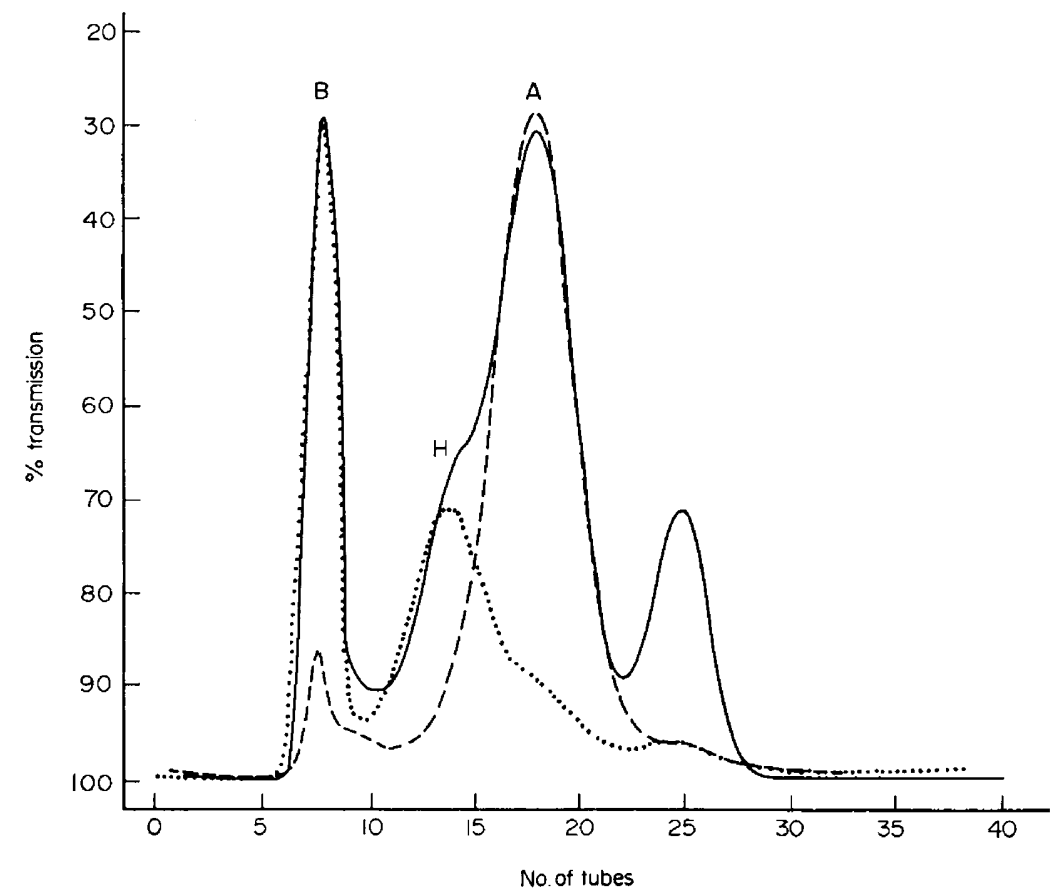

TEXT-FIG. 1. Diagram of protein distribution in eluates from Sephadex G-200 gel filtration of boar seminal plasma $(-)$, A Dial $(\ldots \ldots)$ and B Dial $(\ldots \ldots)$ in acetate buffer, $\mathrm{pH} 4 \cdot 0, I=0 \cdot 3$. A, A peak; B, B peak; H, Haemagglutinin peak. Graphs of separate gel filtrations are combined.

can be seen that very similar patterns were revealed by the two fluids and the three major proteins, $\mathrm{A}, \mathrm{B}$ and $\mathrm{H}$, and the trailing peak (around tube no. 25) of low molecular weight compounds could be identified. The separation of the seminal plasma and vesicular secretion into A Seph and B Seph was clear. The A Dial revealed Protein A and a residue of Protein B, while B Dial was fractionated to Proteins B and $\mathrm{H}$.

The separations of the epididymal plasma proteins on Sephadex G-200 at $\mathrm{pH} 4.0$ and $\mathrm{pH} 7 \cdot 0$ are shown in Text-figs $3(\mathrm{a})$ and $3(\mathrm{~b})$, respectively. 


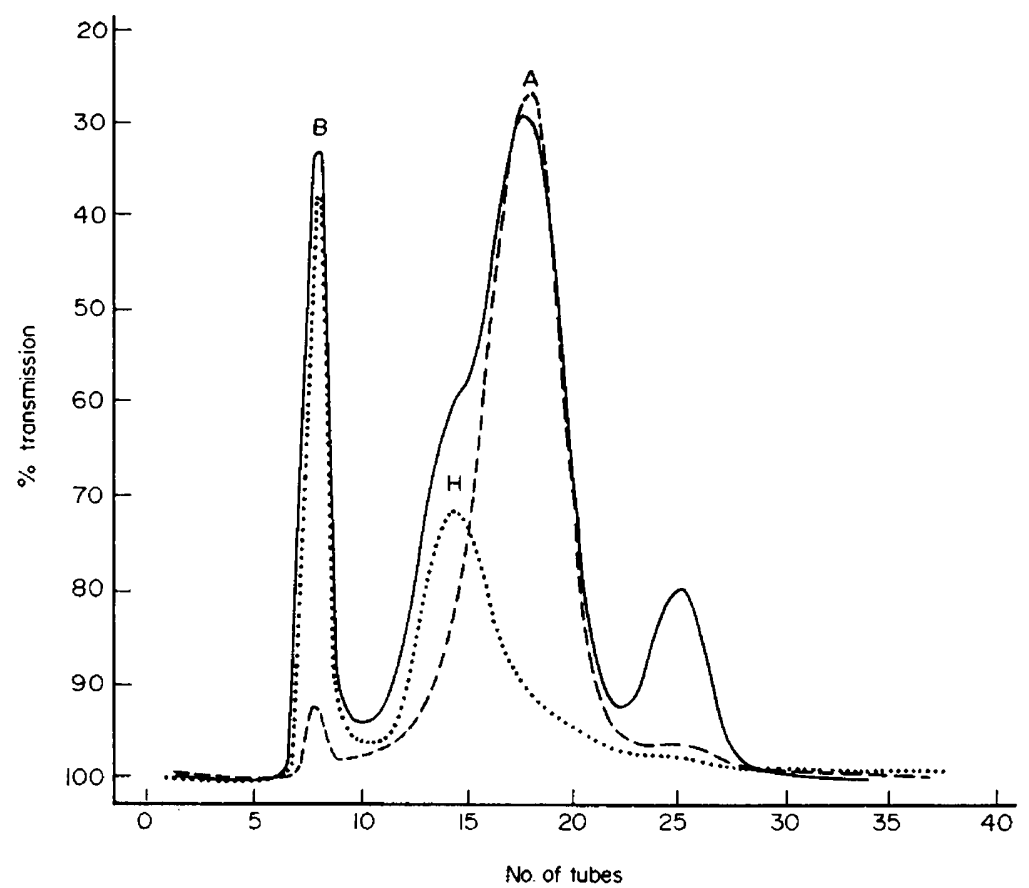

TEXT-FIG. 2. Diagram of protein distribution in eluates from Sephadex G-200 gel filtration of boar vesicular secretion $(-)$, A Dial $(\ldots .$.$) and B Dial (\ldots \ldots)$ in acetate buffer, $\mathrm{pH} 4.0, I=0.3$. A, A peak; B, B peak; H, Haemagglutinin peak. Graphs of separate gel filtrations are combined.

A clear separation into three major protein fractions was obtained. The first peak showed a considerable haziness and a large number of small peaks on it and did not exhibit a consistent pattern for all the replicates. The other two peaks were separated very clearly from the first and always appeared in the same positions on the column. The separation of these proteins by the $\mathrm{pH} 7.0$ buffer was less effective, as can be judged from the shape of the peaks.

The protein pattern of the Sepharose $6 \mathrm{~B}$ gel filtration of the epididymal plasma is presented in Text-fig. 4. Three major proteins were also detected in this case, although their separation showed a different pattern. The degree of haziness in the first peak was greater than in the Sephadex G-200 column and the shape of the peak varied slightly from sample to sample. The separation of the other two peaks was less effective than on the Sephadex column.

\section{Gel disc electrophoresis}

The electrophoretic patterns of the proteins of the seminal plasma and the vesicular secretion and of their fractions are shown in Text-figs 5 and 6 , respectively. The seminal plasma exhibited twelve proteins of which Nos 2 to 9 appeared in the A Seph and Nos 11 and 12 in the B Seph; No. 10 appeared in both fractions. Protein No. 1 could not be detected in any of the fractions, probably owing to its low concentration in the seminal plasma. The A Dial resembled the A Seph except for traces of protein No. 11 in the former and of 


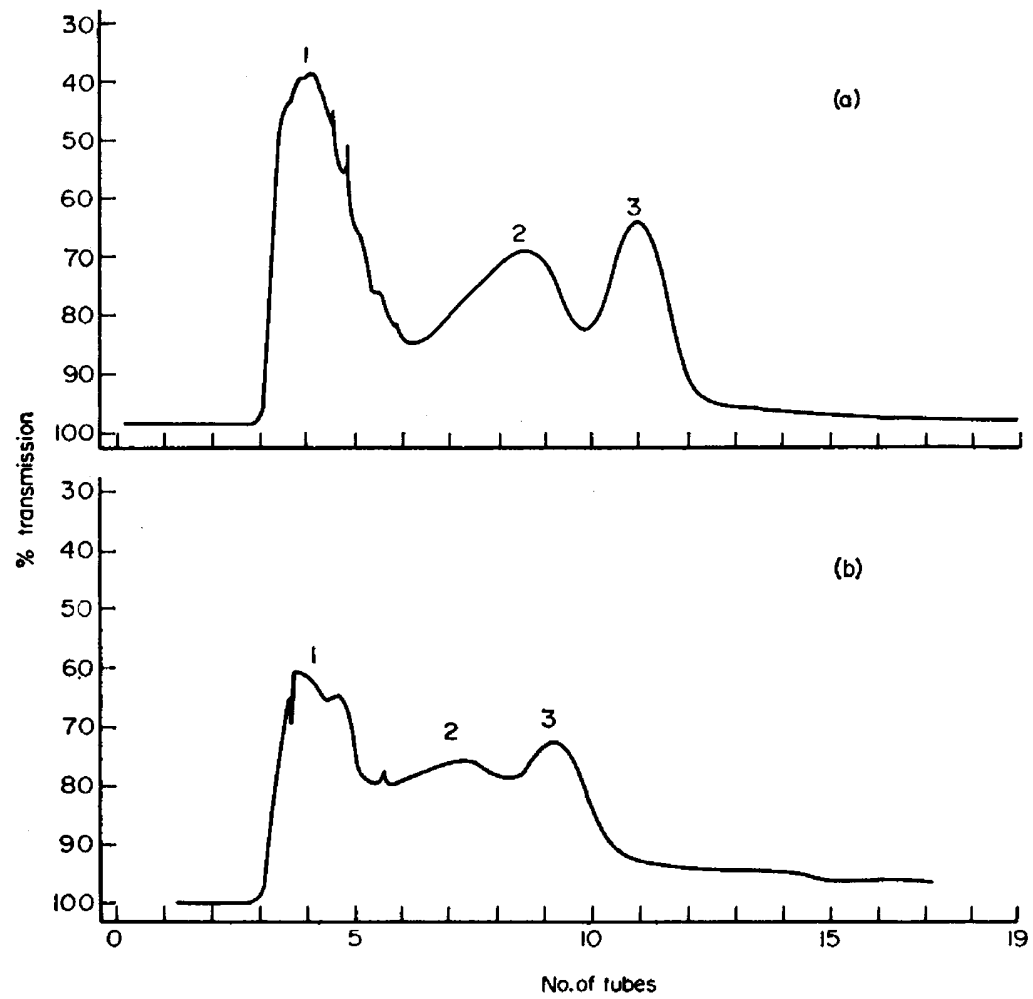

Text-rig. 3. Diagrams of protein distribution in eluates from Sephadex G-200 gel filtration of boar epididymal plasma: (a) in acetate buffer, $\mathrm{pH} 4 \cdot 0, I=0.3$; (b) in phosphate buffer, $\mathrm{pH} 7 \cdot 0, I=0 \cdot 3$.

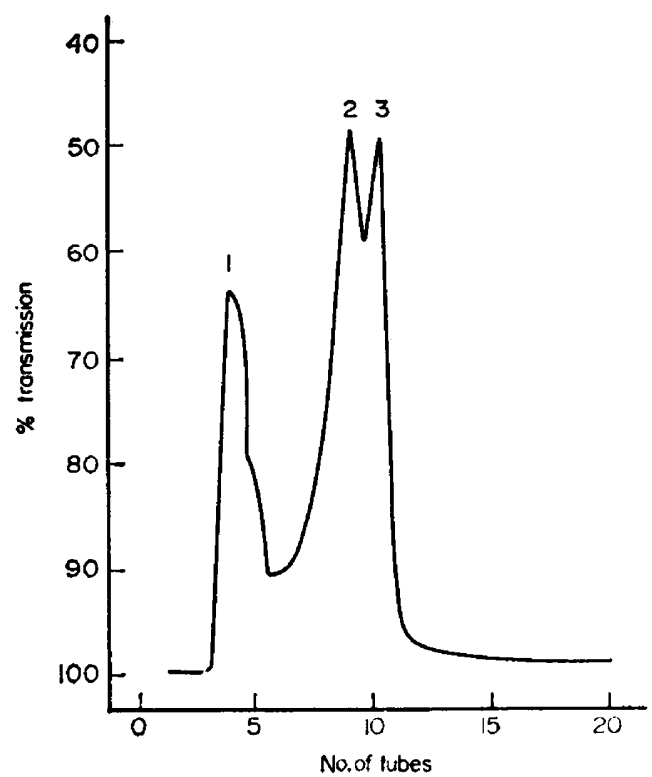

Text-Fig. 4. Diagram of protein distribution in eluates from Sepharose 6B filtration of boar epididymal plasma in acetate buffer, $\mathrm{pH} 4 \cdot 0, I=0 \cdot 3$. 


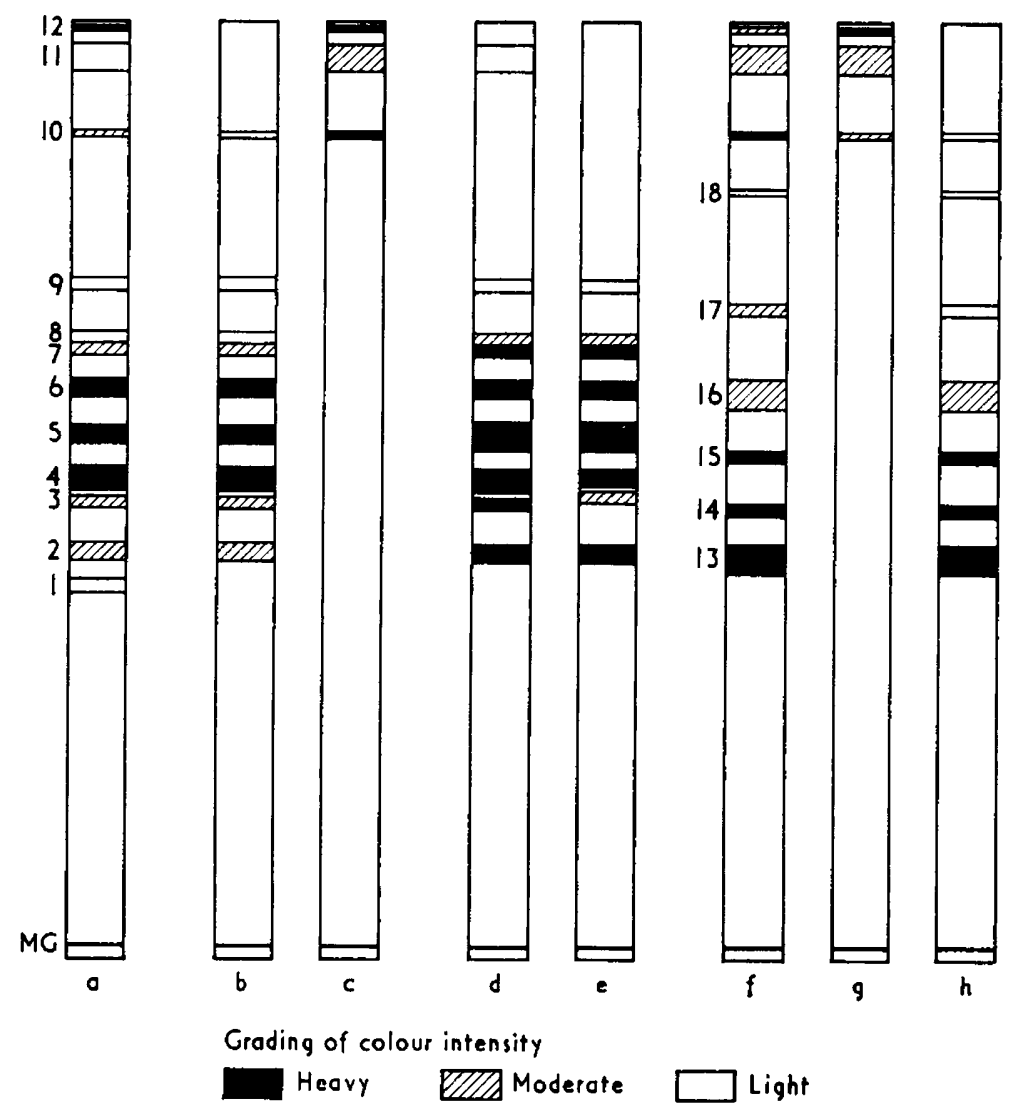

TEXT-FIG. 5. Separation by gel disc electrophoresis at $\mathrm{pH} 4.5$ of: (a) boar seminal plasma; (b) A Seph; (c) B Seph; (d) A Dial; (e) A Seph ex A Dial; (f) B Dial; (g) B Seph ex B Dial; (h) Protein H ex B Dial.

protein No. 10 in the latter. The A Seph ex A Dial did not show either of these two proteins. The B Dial and B Seph contained Proteins Nos 10 to 12. In addition, the B Dial showed six more proteins (Nos 13 to 18) which could not be seen in the seminal plasma pattern. The gel filtration of the B Dial fraction revealed two distinct groups of proteins; B Seph and Protein $\mathrm{H}$. The latter contained proteins Nos 13 to 18 and traces of protein No. 10. The mobility of the most basic of these six proteins was similar to that of proteins Nos 1 and 2 .

The vesicular secretion showed a very similar protein pattern to that of the seminal plasma. The majority of the proteins of the two fluids appeared to be identical and only protein No. 3 of the seminal plasma could not be detected in the vesicular secretion. The distribution of the proteins between the A Seph and B Seph was also similar to that observed in the seminal plasma. The A Dial and A Seph ex A Dial showed the same pattern and no traces of any of the B Seph proteins were found. This was probably the result of a better separation of the A Dial from the B Dial in the dialysis. In the B Dial, only four new proteins appeared, all of them in Protein $\mathrm{H}$.

The electrophoretic separation of the epididymal plasma proteins and of 


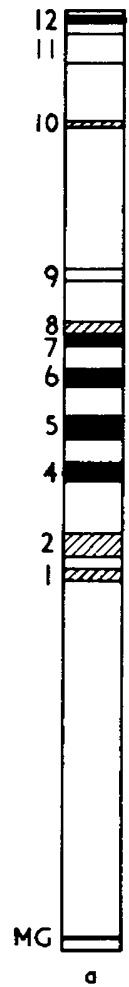

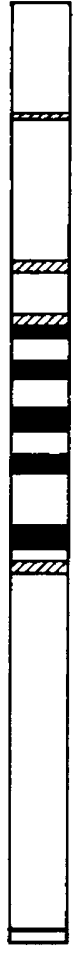

b

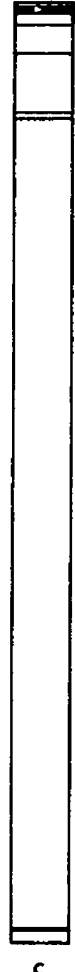

Grading of colour intensity

Heary
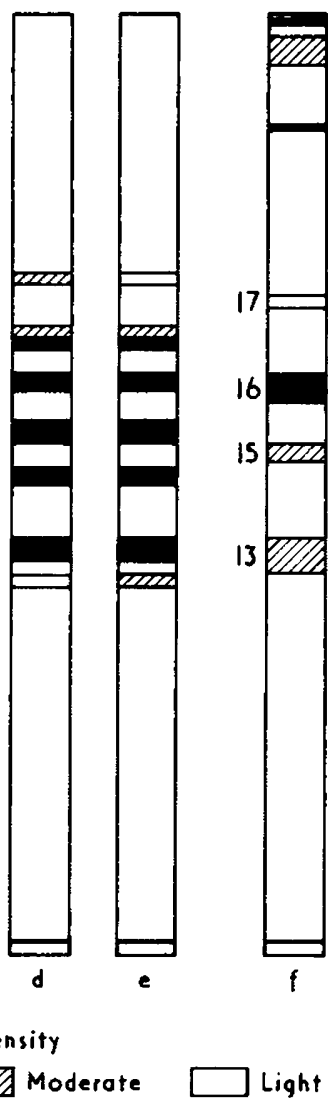

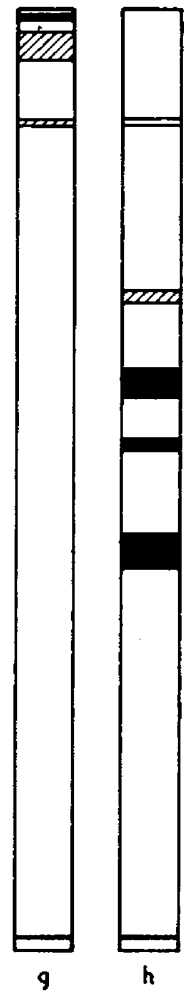

TEXT-FIG. 6. Separation by gel disc electrophoresis at $\mathrm{pH} 4.5$ of: (a) boar vesicular secretion; (b) A Seph; (c) B Seph; (d) A Dial; (e) A Seph ex A Dial; (f) B Dial; (g) B Seph ex B Dial; (h) Protein H ex B Dial.

their fractions is shown in Text-fig. 7. Fourteen proteins were identified in the epididymal plasma of which Nos 2, 4, 6, 9, 12, 13 and 14 were detected in the first peak eluted with $\mathrm{pH} 4.0$ buffer from the G-200 column. Another protein No. 15, which could not be identified in the epididymal plasma pattern, was also found in this peak. The combined second and third peaks exhibited proteins Nos 1, 2, 3, 4, 5, 6, 7, 8, 10, 14 and 15. Proteins Nos 2, 4, 6, 14 and 15 probably possessed intermediate positions between the major peaks (Text-fig. 3) in terms of molecular weights and sizes.

The first peak obtained from the G-200 column with the $\mathrm{pH} 7 \cdot 0$ buffer revealed a single protein (No. 14). However, not all the other proteins could be identified in the pattern of the combined second and third peaks; Nos 3, 9, 11, 12 and 13 were missing. In addition, protein No. 15 and another protein (No. 16) were detected.

The first peak obtained from the Sepharose 6B column did not reveal any protein by electrophoresis at either $\mathrm{pH}$ value. This was in agreement with the extremely low nitrogen content of this eluate. Furthermore, all the epididymal plasma proteins could be identified in the pattern of the second and third peaks. 

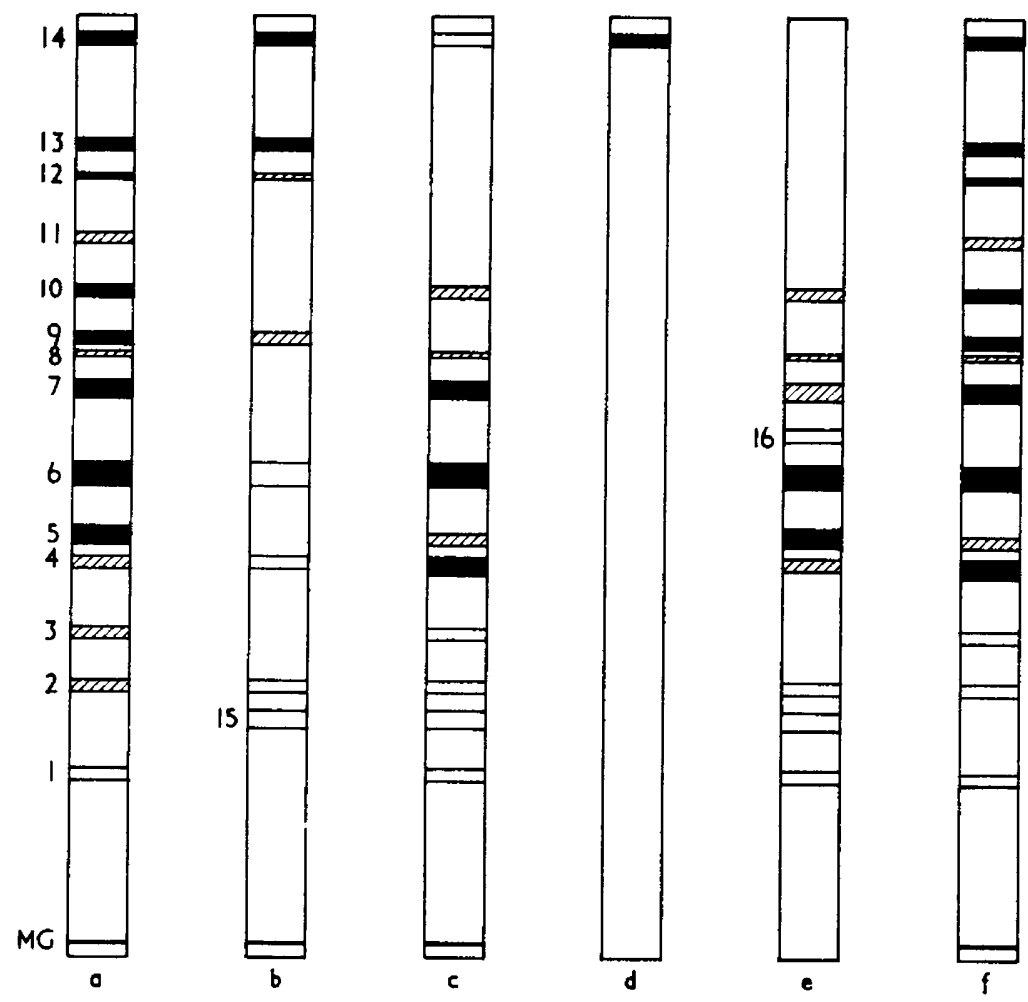

Grading of colour intensity

Heary

QDTA Moderote

Light

TExT-FIG. 7. Separation by gel disc electrophoresis at $\mathrm{pH} 4.5$ of: (a) boar epididymal plasma; (b) first peak from Sephadex G-200 gel filtration eluted with acetate buffer, $\mathrm{pH}$ $4 \cdot 0, I=0 \cdot 3$; (c) second and third peaks from the same Sephadex G-200 gel filtration; (d) first peak from Sephadex G-200 gel filtration eluted with phosphate buffer, pH 7.0, $I=0.3 ;$ (e) second and third peaks from the same Sephadex G-200 gel filtration; (f) second and third peaks from Sepharose $6 \mathrm{~B}$ gel filtration eluted with acetate buffer, $\mathrm{pH}$ $4 \cdot 0, I=0 \cdot 3$.

It should be pointed out that proteins Nos 4 and 5 showed different staining intensities in relation to the other proteins, No. 5 being more distinct in the epididymal plasma and in the fractions separated at $\mathrm{pH} 7.0$ whereas No. 4 appeared as the major protein of the two in the samples separated at $\mathrm{pH} 4 \cdot 0$ (G-200 and Sepharose 6B).

In this part of the work, the full contribution of the epididymal plasma proteins could not be positively identified due to the masking by proteins of similar mobility arising from the seminal vesicle secretion. It would seem, however, that the epididymal contribution is small.

\section{Isoelectric focusing}

The patterns obtained for the proteins of the seminal plasma and vesicular secretion and of their fractions are presented in Plates 1 and 2, respectively. Eighteen proteins were identified in the seminal plasma pattern (Pl. 1, Fig. 1), 


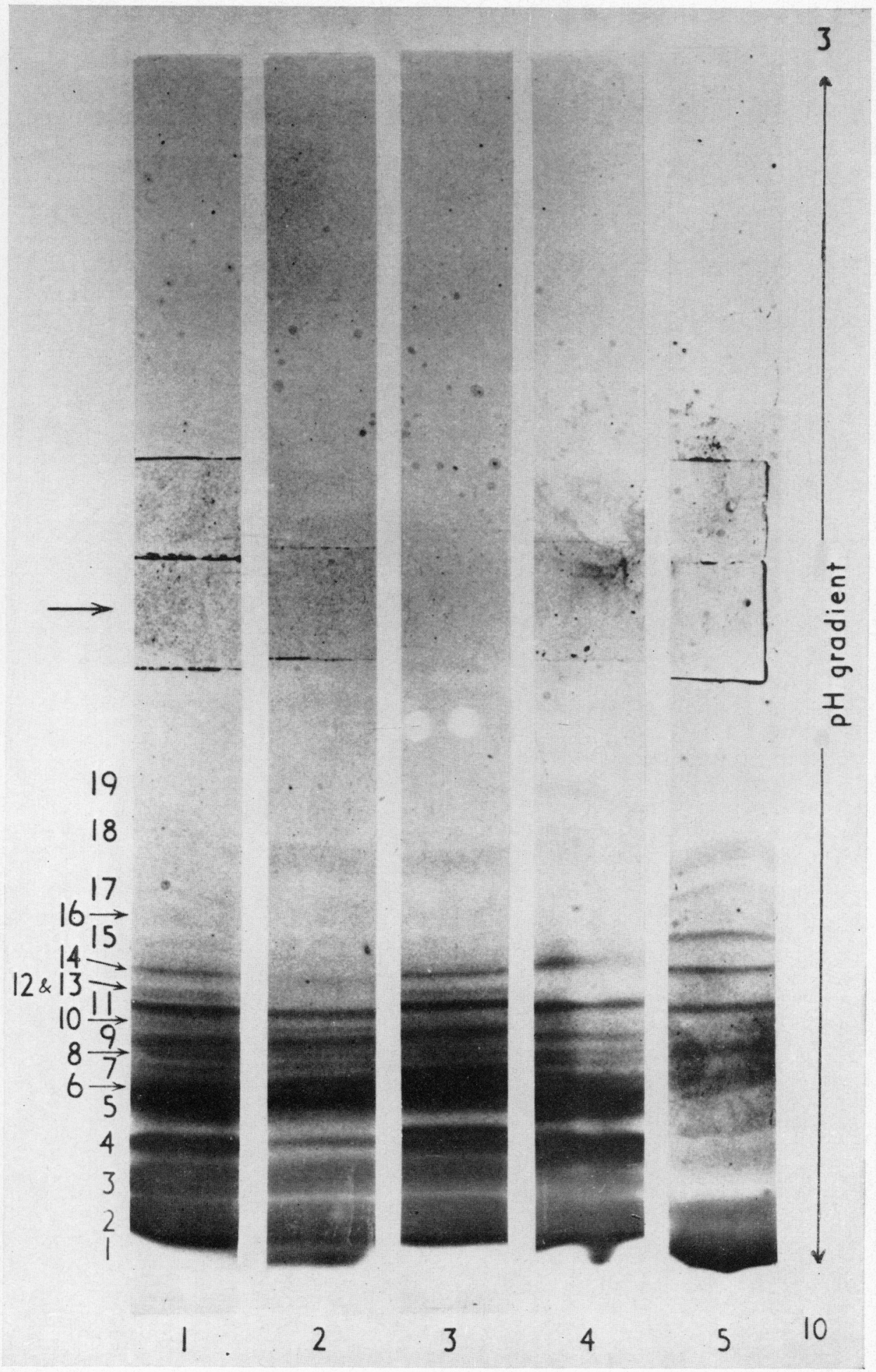

Isoelectric focusing on an acrylamide-ampholine plate of $\mathrm{pH} 3$ to 10 of: (FrG. 1) boar

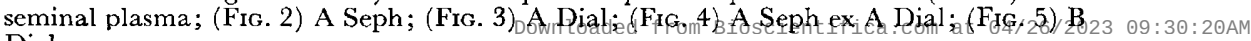
Diel. 


\section{PLATE 2}

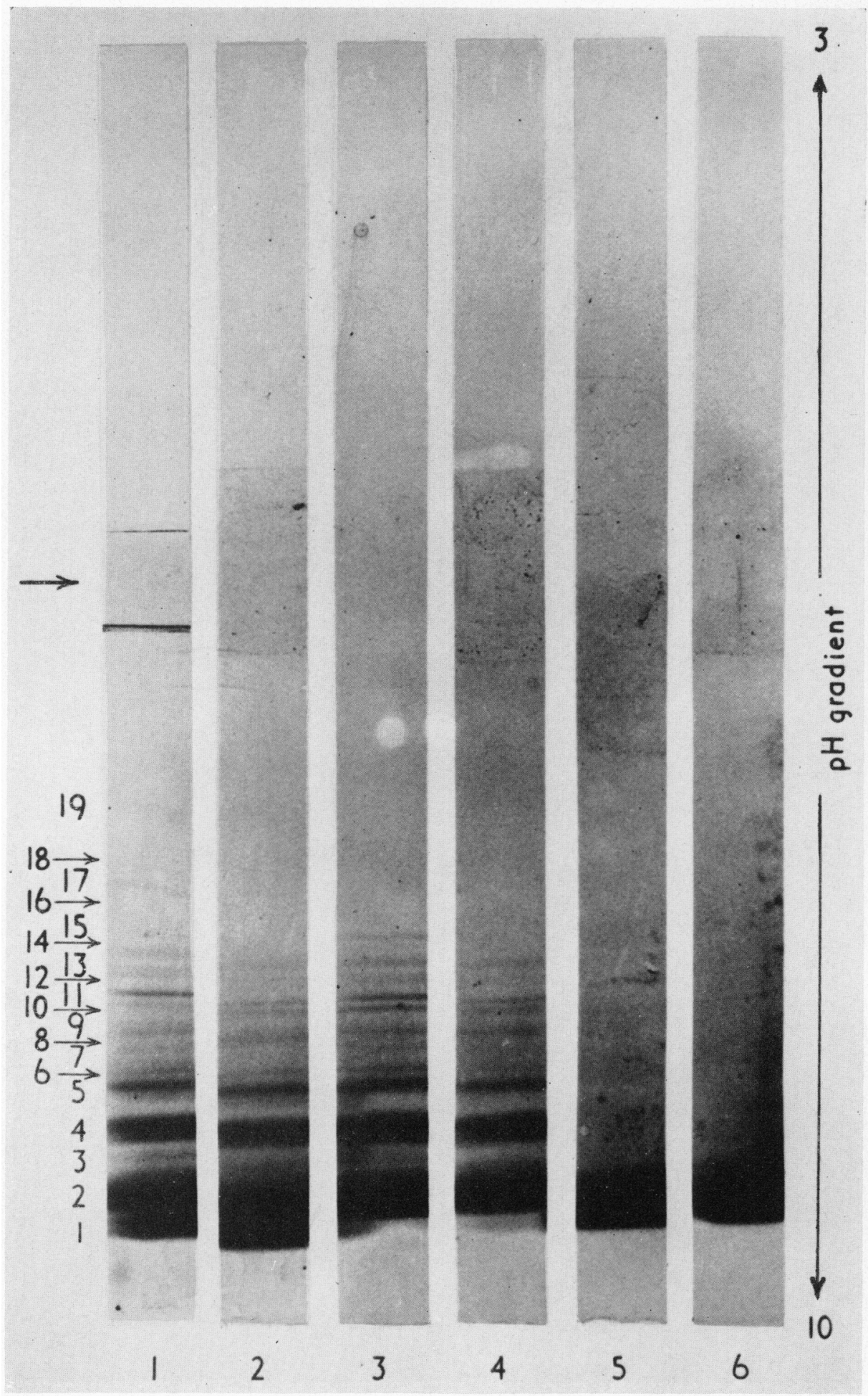

Isoelectric focusing on an acrylamide-ampholine plate of $\mathrm{pH} 3$ to 10 of: (Fig. 1) boar

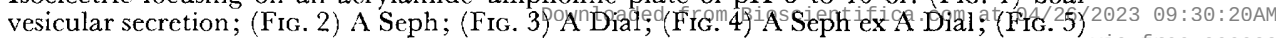
B Dial; (FIG. 6) protcin H ex B Dial. 


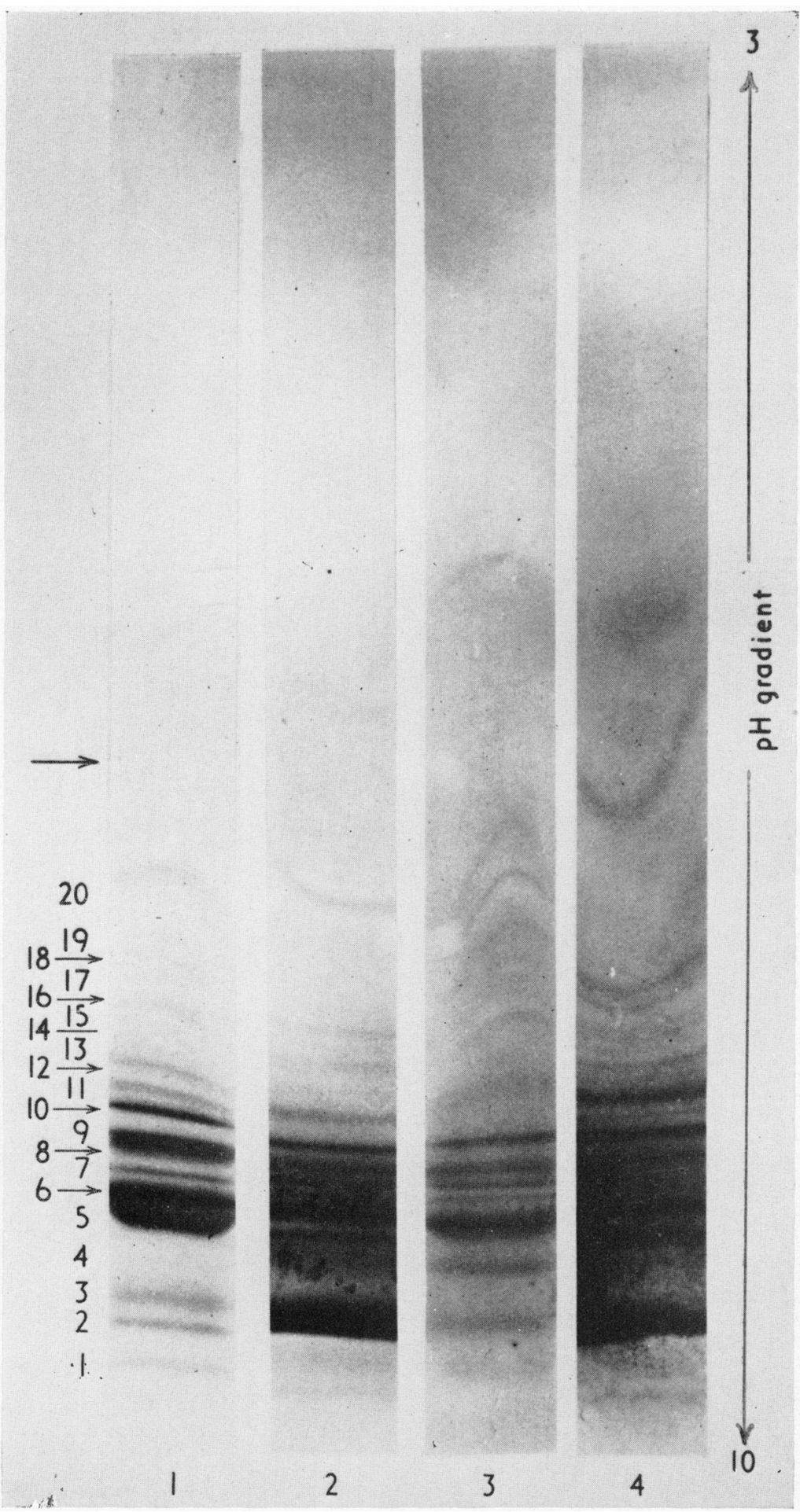

Isoelectric focusing on an acrylamide-ampholine plate of $\mathrm{pH} 3$ to 10 of: (FIG. 1) boar epididymal plasma; (FIG. 2) second and third peaks from Sephadex G-200 gel filtration eluted with acetate buffer, $\mathrm{pH} 4 \cdot 0, I=0 \cdot 3$. (FIG $_{3} 3$ ) second and third peaks from Sephadex G-200 gel filtration eluted with phosphate buffer, $\mathrm{pH} 7 \cdot 0, I=0.3 ;$ (FIG. 4) second and third peaks eluted with acetate buffer, $\mathrm{pH} 4 \cdot 0, I=0 \cdot 3$ from Sepharose $6 \mathrm{~B}$ column. 
No. 1 being present only in traces. The A Seph contained the majority of the seminal plasma proteins, but lacked Nos 12, 13,15, 16 and 17, apparently due to their low concentration in this fraction. In contrast to the seminal plasma pattern, protein No. 1 appeared very distinctly at the basic end of the protein pattern. The A Dial lacked protein No. 1, but otherwise showed the same pattern as the seminal plasma. The A Seph ex A Dial revealed a very similar pattern to that of A Dial, although lacking proteins Nos 12, 13,16 and 17, and presented another protein (No. 19). The main proteins in the B Dial fraction were Nos 1 and 2 accompanied by a few minor proteins. Protein No. 2 and the minor proteins appeared to be residues of Protein A contaminating the B Dial precipitate in the dialysis sac. Protein B Seph did not show any migrating bands and remained at source as stained material (cf. Lavon \& Boursnell, 1971).

The vesicular secretion revealed a protein pattern similar to that of the seminal plasma, and most of the proteins possessed identical isoelectric points, although they were present in different proportions in the two fluids. Protein No. 1 appeared as a major component which was almost entirely absent in the A Dial and A Seph ex A Dial fractions. The B Dial and Protein H ex B Dial showed similar patterns in which protein No. 1 was dominant. Residues of protein No. 2 could also be detected, although to a lesser extent in Protein $\mathrm{H}$ ex B Dial. The B Seph fraction, as in the seminal plasma, did not show any migrating proteins.

The protein patterns of the epididymal plasma and of its gel filtration fractions are presented in Plate 3 . The patterns obtained for the combined second and third peaks eluted with the $\mathrm{pH} 4.0$ buffer from either Sephadex G-200 or Sepharose 6B columns differed considerably from that of the native epididymal plasma, proteins Nos 5 and 6 showing different shapes whilst protein No. 3 appeared as the main component. It seems likely that proteins $5,6,8$ and 9 of the epididymal plasma can be identified in Nos 5, 6, 8 and 9 of the seminal plasma. The proteins separated at $\mathrm{pH} 7.0$ revealed a similar pattern to that of the native fluid, although a few of the more acidic proteins (Nos 12 and 13) were absent. These might correspond to those which could not be detected in any of the gel disc electrophoresis peaks. Protein No. 11 was absent in Pl. 3, Figs 2 and 3 (second and third peaks from Sephadex G-200 columns) and could belong to the first peak eluted from these columns. The Sepharose 6B (Pl. 3, Fig. 4) showed the complete number of proteins found for the epididymal plasma.

\section{DISCUSSION}

The seminal plasma and vesicular secretion showed almost identical distribution patterns of proteins in eluates collected from Sephadex G-200 columns. The A Dial and B Dial fractions prepared from both fluids by dialysis also presented similar patterns and enabled the identification of the three major proteins, A, B and $\mathrm{H}$, which were reported previously (Boursnell, Briggs \& Cole, 1968; Boursnell, Cole \& Briggs, 1968; Boursnell \& Briggs, 1969). The present study confirmed that the majority of the seminal plasma proteins originate in the seminal vesicle glands (Boursnell \& Briggs, 1969). 
The Sepharose $6 \mathrm{~B}$ separation of epididymal plasma at $\mathrm{pH} 4.0$ revealed a different distribution of proteins from the Sephadex G-200, although three major peaks were identified. The protein patterns obtained with both gel filtration media differed from those obtained for the seminal plasma and vesicular secretion.

A haze always occurred in the excluded peak of gel filtration at all $\mathrm{pH}$ values from 4 to 9 for all the samples studied. This haze could be eliminated by prior centrifugation $(35,000 \mathrm{~g}$ for $20 \mathrm{~min})$ of the native fluids, which resulted in somewhat smaller peaks, and might represent foreign matter such as cell débris and bacteria.

The gel filtration studies in the present paper are not in agreement with those of Schellpfeffer \& Hunter (1970), who suggested that peak B of the seminal plasma originated in the epididymal and testicular fluids and that the contribution of the seminal vesicles to this peak was not significant. It is most likely that some of the epididymal plasma proteins are present in this peak, as can be assumed from the slightly lower ratio between peaks A and B in the seminal plasma in comparison to the vesicular secretion (Text-figs 1 and 2). However, the thirtyfold dilution of the epididymal plasma in the seminal plasma (Mann \& Glover, 1954; U. Lavon, P. A. Briggs and J. C. Boursnell, unpublished data) ruled out a major contribution of the epididymal plasma to any of the peaks. Furthermore, electrophoretic separations of B Seph prepared from seminal plasma and vesicular secretion gave identical patterns and no epididymal plasma proteins could be detected.

The gel disc electrophoretic patterns of the seminal plasma and the vesicular secretion were very similar, as was reported by Lavon \& Boursnell (1971), though protein No. 3 could not be detected in the vesicular secretion. This protein could originate in the epididymal plasma or in one of the other accessory secretions. The inability to identify many of the epididymal plasma proteins in the seminal plasma pattern is in agreement with previous findings (Lavon \& Boursnell, 1971) where only one possible protein common to both fluids was reported, following electrophoresis at $\mathrm{pH} 4 \cdot 5$.

The number of proteins identified in the seminal plasma was greater than that found by Einarsson, Crabo \& Ekman (1970), who used paper electrophoresis at $\mathrm{pH} 8.9$. At this $\mathrm{pH}$ value, they failed to separate the basic proteins which comprise 80 to $90 \%$ of the total (Boursnell et al., 1966) and only the acidic proteins present in the seminal plasma migrated. They were able, however, to identify two of the epididymal plasma proteins which migrated at this $\mathrm{pH}$ value in the seminal plasma pattern. These results are in agreement with those of Lavon \& Boursnell (1971), in which four proteins appeared to be common to the two fluids following gel disc electrophoresis at $\mathrm{pH} 8 \cdot 6$.

Protein A appeared as a group of fast moving proteins, and there were only small differences between the seminal plasma and vesicular secretion; protein No. 3 was present in the former and No. 1 in the latter.

Fraction B Seph showed two acidic proteins (Nos 13 and 14) in close agreement with the value of 4.6 found by Boursnell \& Briggs (1969). One of the proteins (No. 10) appeared in both Proteins A and B which most probably indicates an intermediate position between the major peaks in terms of size and 
molecular weight. This protein appeared also in the B Dial, B Seph ex B Dial and Protein $\mathrm{H}$ of both seminal plasma and vesicular secretion and could well correspond to the initial part of Protein H of Boursnell, Briggs \& Cole (1968) and Boursnell, Cole \& Briggs (1968) and of the haemagglutinating factor of Schellpfeffer \& Hunter (1970). It may also represent the fast moving haemagglutinin with negative mobility mentioned by Boursnell \& Briggs (1969).

Six proteins were found in the B Dial fraction (only four in the B Dial ex vesicular secretion) which could not be detected in the seminal plasma pattern. This could be due to their low concentration in the fluid and to the fact that they were masked by the Protein A components. By electrophoresis of protein $\mathrm{H}$, those proteins were identified as haemagglutinins. This confirmed the findings of Nelson \& Boursnell (1966) who reported the existence of apparently seven discrete haemagglutinins in the seminal plasma following separation on Amberlite XE-64. The existence of a number of haemagglutinins is also supported by the wide dispersion of Protein $\mathrm{H}$ in the ultracentrifuge (Boursnell \& Briggs, 1969). The smaller number of haemagglutinins in the vesicular secretion was probably due to variations between animals.

All the bands which appeared on the plate except No. 1, identified (by running the B Dial fraction on the isoelectric focusing plate) as the haemagglutinating protein, belonged to the Protein A Group. The numerous bands of this group occupied about $2.5 \mathrm{pH}$ units ranging from 6.5 to $9 \cdot 0$. The different isoelectric points obtained for the various components of protein $\mathrm{A}$ are in agreement with the differences in mobilities of the same proteins in the gel disc electrophoresis. These findings contrast with those of the ultracentrifugation studies of Boursnell \& Briggs (1969) in which Protein A appeared to be homogeneous. It is probable, however, that these proteins possess different isoelectric points but equal molecular weights.

The haemagglutinins identified by the gel disc electrophoresis appeared on the plate as a single band at the basic end of the $\mathrm{pH}$ gradient and deposited a trail of stained material behind it. Its isoelectric point was in the range reported by Boursnell \& Briggs (1969). One reason for the appearance of a single band is apparently the precipitation of some of the haemagglutinins along the migration path as a result of their low solubility in water, especially in the presence of traces of acidic proteins (Nelson \& Boursnell, 1966).

The vesicular secretion and its fractions exhibited similar isoelectric focusing patterns to those of the seminal plasma. Small variations between the samples are almost certainly the result of collection from different sources.

In connection with the gel filtration and electrophoresis of epididymal plasma, a few points should be considered. (1) It is possible that the proteins which were missing from the gel disc electrophoretic patterns of the $\mathrm{pH} 7.0$ gel filtration combined with the phosphate present in the buffer and were trapped on the column or that they became insoluble and precipitated while centrifuging the samples before electrophoresis. (2) The Sepharose 6B was shown to be inadequate for the separation of epididymal plasma proteins as no proteins could be found in the first peak by electrophoresis at $\mathrm{pH} 4.5$ or $8 \cdot 6$. This peak probably presented foreign matter which gave false u.v. absorption. (3) The molecular weights of the proteins which were identified in the first peak of Sephadex G- 
200 (Nos 9, 1213 and 14) lay between the exclusion limits of the Sephadex and the Sepharose. It is possible that they are present in peak B of the seminal plasma as was suggested by Schellpfeffer \& Hunter (1970), although in very low concentrations.

From the isoelectric focusing patterns of the epididymat plasma, it is very likely that proteins Nos 5, 6, 8 and 9 of the epididymal plasma can be identified in Nos 5, 6, 8 and 9 of the seminal plasma. This conclusion is supported by the findings of U. Lavon, P. A. Briggs and J. C. Boursnell (unpublished data) on the protein patterns of boar split-ejaculate fractions.

The changes recorded in positions and staining intensities of various proteins in the gel disc electrophoresis and isoelectric focusing of the $\mathrm{pH} 4 \cdot 0$ gel filtration fractions (Text-fig. 7 and Plate 3 ) compared to those of the epididymal plasma and the $\mathrm{pH} \mathrm{7.0} \mathrm{gel} \mathrm{filtration} \mathrm{fractions} \mathrm{cannot} \mathrm{be} \mathrm{fully} \mathrm{explained,} \mathrm{but} \mathrm{it} \mathrm{seems}$ likely that they were caused by the low $\mathrm{pH}$ of the acetate buffer. It is also possible that the proteins were affected by the acetate included in the composition of the buffer as opposed to the phosphate. Such alterations could not be observed in any of the seminal plasma and vesicular secretion proteins, although the same buffer was used in gel filtration of these fluids.

It can be concluded from the current work that the origin of the majority of the seminal plasma proteins is in the seminal vesicles and that the quantitative contribution of the epididymal plasma to any of the peaks is small. It was also found that the major proteins, $\mathrm{A}, \mathrm{B}$ and $\mathrm{H}$, are mixtures of large numbers of proteins. In the previous publications, Proteins A and B were reported to be electrophoretically pure by free boundary electrophoresis (Boursnell \& Briggs, 1969), but the heterogeneity of Protein H was indicated (Nelson \& Boursnell, 1966).

\section{ACKNOWLEDGMENTS}

We are greatly indebted to $\mathrm{Mr} \mathrm{P}$. Miles for constructing the apparatus used in the electrophoresis and to $\mathrm{Mr} \mathrm{R}$. J. Patman for the photography of the stained plates.

We are also grateful to $\mathrm{Mr} \mathrm{I}$. Wilmut and Mr J. Doggett for the collection of boar semen and to Mr D. J. Kirk and Mr H. C. Toates for arranging the collection of fresh slaughterhouse material.

One of the authors (U.L.) wishes to express his gratitude to the Royal College of Veterinary Surgeons Trust Fund in London for awarding him the MLC/ RCVS Senior Fellowship in Animal Health for the years 1970-72 which enabled him to carry out this research.

\section{REFERENCES}

Boursnell, J. C. \& Briggs, P. A. (1969) Boar seminal plasma proteins. II. Electrophoretic identification of the haemagglutinin. 7. Reprod. Fert. 19, 157.

Boursnele, J. C., Briggs, P. A. \& Cole, D. M. (1968) Boar vesicular secretion proteins; further comparisons with seminal plasma proteins. F. Reprod. Fert. 16, 457.

Boursnelt, J. C., Cole, D. M. \& Briggs, P. A. (1968) Boar seminal plasma proteins; further observations on the haemagglutinating protein and on the coagulation by heat of some seminal plasma proteins. 7. Reprod. Fert. 17, 533.

Boursnell, J. C., Hartree, E. F. \& Briggs, P. A. (1970) Studies of the bulbo-urethral (Cowper's)gland mucin and seminal gel of the boar. Biochem. $7.117,981$. 
Boursnell, J. C. \& Nelson, M. (1965) Studies on boar seminal plasma proteins. II. An investigation on the heat-coagulable component ('fraction A'). Biochim. biophys. Acta, 104, 181.

Boursnell, J. C., Nelson, M. \& Cole, D. M. (1966) Studies on boar seminal plasma proteins. III. Fractionation by gel filtration, ion exchange and other means. Biochim. biophys. Acta, 117, 134.

Davis, B. J. (1964) Disc electrophoresis. II. Method and application to human serum proteins. Ann. N.Y. Acad. Sci. 121, 404.

Einarsson, S., Crabo, B. \& Exman, L. (1970) A comparative study on the chemical composition of plasma from the cauda epididymidis, semen fractions, and whole semen in boars. Acta vet. scand. 11, 156.

LASLEY, J. F. \& Bogart, R. (1944) A comparative study of epididymal and ejaculated spermatozoa of the boar. F. Anim. Sci. 3, 360.

Lavon, U. (1972) Characterization of boar, bull, ram and rabbit seminal plasma proteins by gel disc electrophoresis and isoelectric focusing on polyacrylamide. F. Reprod. Fert. 31, 29.

Lavon, U. \& Boursnell, J. C. (1971) Characterization of boar seminal plasma, vesicular secretion and epididymal plasma proteins by gel disc electrophoresis and isoelectric focusing on polyacrylamide. 7. Reprod. Fert. 27, 227.

ManN, T. \& Glover, T. C. (1954) Contribution of the seminal vesicles towards the composition of whole semen. F. Endocr. 10, iv.

Miller, G. L. \& Golder, R. H. (1950) Buffers of pH 2 to 12 for use in electrophoresis. Archs Biochem. $29,420$.

Nelson, M. \& Boursnell, J. C. (1966) Studies on boar seminal plasma proteins. IV. Isolation of factors with haemagglutinating and protein-precipitating activity. Biochim. biophys. Acta, 117, 144.

Reisfeld, R. A., Lewis, U. J. \& Williams, D. E. (1962) Disk electrophoresis of basic proteins and peptides on polyacrylamide gels. Nature, Lond. 195, 281.

Schellpferfer, D. A. \& Hunter, A. G. (1970) Electrophoretic and gel filtration behaviour of boar seminal plasma proteins before and after removal of accessory sex glands. F. Reprod. Fert. 23, 291.

Walton, A. (1956) The initiation of motility in mammalian spermatozoa. Proc. Soc. Study Fert. 8, 53. 